\title{
ANALISIS PERILAKU BERISIKO PENULARAN HIV/AIDS DENGAN PENDEKATAN HEALTH BELIEF MODEL PADA TKBM DI PELABUHAN KOTA PADANG
}

\author{
Sri Mindayani ${ }^{1}$, Hilda Hidayat ${ }^{2}$ \\ ${ }^{1}$ Fakultas Kesehatan Masyarakat, Universitas Baiturrahmah, Jalan Raya By Pass Km 15 Kelurahan Air Pacah Padang \\ email: srimindayani@fkm.unbrah.ac.id \\ ${ }^{2}$ Fakultas Kesehatan Masyarakat Universitas Baiturrahmah, Jalan Raya By Pass Km 15 Kelurahan Air Pacah Padang \\ email: hildahidayat15@gmail.com
}

Submitted: 08-11-2019, Reviewer: 21-11-2019, Accepted: 05-12-2019

\begin{abstract}
HIV AIDS in Indonesia has a high risk in the Bongkat Muat Workforce (TKBM) population. TKBM is a potential male WPS customer. Based on the STBP in 2015, cases of HIV / AIDS in TKBM 2007 (0.8\%), 2011 decreased (0.7\%) and 2015 increased (0.82\%). The results of the initial survey of the increase in HIV / AID cases in 2014 were 15 cases, in 2015 there were 21 cases and in 2016 there were 24 cases. The purpose of this study is to find out the risk behaviors of HIV / AIDS transmission at TKBM in the Port of Padang City and the factors that influence them. The purpose of the study was to analyze factors related to HIV / AIDS transmission strategies in TKBM in the Port of Padang City. This type of analytical research with cross sectional design. Population of 782 people and a sample of 90 people with cluster sampling technique. Data analysis with univariate \& bivariate analysis. The result showed there was no relationship between perception vulnerability, perceived benefits, perceived obstacles, perceived impulses with risk behaviors of HIV / AIDS transmission.
\end{abstract}

Keywords : HIV/AIDS, Risk Behaviour, Loading Worker

\begin{abstract}
ABSTRAK
HIV AIDS di Indonesia memiliki risiko tinggi pada populasi Tenaga Kerja Bongkat Muat (TKBM). TKBM merupakan pria potensial pelanggan WPS. Berdasarkan STBP 2015, kasus HIV/AIDS pada TKBM 2007 (0,8\%), 2011 menurun (0,7\%) dan 2015 meningkat (0,82\%). Hasil survey awal peningkatan kasus HIV/AID 2014 terdapat 15 kasus, 2015 terdapat 21 kasus dan 2016 terdapat 24 kasus. Tujuan penelitian mengetahui perilaku berisiko penularan HIV/AIDS pada TKBM di Pelabuhan Kota Padang dan faktor yang mempengaruhinya. Tujuan penelitian untuk menganalisis faktor yang berhubungan dengan perilaku berisiko penularan HIV/AIDS pada TKBM di Pelabuhan Kota Padang. Jenis penelitian analitik dengan desain cross sectional. Populasi 782 orang dan sampel 89 orang. Pengambilan sampel dengan teknik cluster sampling. Analisis data dilakukan dengan analisis univariat dan bivariat. Hasil penelitian menunjukkan tidak adanya hubungan antara umur, pendidikan, suku, tekanan sosial, pengetahuan, persepsi keparahan, persepsi manfaat, persepsi hambatan, persepsi dorongan dengan perilaku berisiko penularan HIV/AIDS.
\end{abstract}

Kata Kunci : HIV/AIDS, Perilaku Berisiko, TKBM

\section{PENDAHULUAN}

Indonesia merupakan negara dengan jumlah kasus HIV paling banyak di Asia Tenggara yaitu diperkirakan 48.000 kasus. Di ASIA, Indonesia menempati urutan ketiga terbesar dalam kasus HIV/AIDS (1). Jumlah kasus HIV di Indonesia pada saat ini terus mengalami peningkatan dari tahun ke tahun. Pada tahun 2014 terdapat 32.711 kasus, tahun 2015 terdapat 30.395 kasus dan pada tahun 2016 terdapat 41.250 kasus. 
HIV AIDS di Indonesia terkonsentrasi pada kelompok-kelompok populasi tertentu (populasi kunci) yang memiliki risiko tinggi penularan HIV terkait perilaku mereka, salah satunya yaitu Tenaga Kerja Bongkat Muat (TKBM). TKBM merupakan pria yang potensial menjadi pelanggan WPS (2). Berdasarkan STBP tahun 2015, jumlah kasus HIV/AIDS pada populasi TKBM tahun 2007 yaitu $0,8 \%$, tahun 2011 menurun menjadi $0,7 \%$ dan tahun 2015 meningkat menjadi 0,82\% (3).

Data dari Dinkes Kota Padang tahun 2017, menunjukkan jumlah kasus HIV sebanyak 300 orang, dimana paling banyak pada laki-laki yaitu 297 orang dan pada perempuan 71 orang (4). Hasil survey awal di puskesmas kawasan pelabuhan Kota Padang, menunjukkan trend peningkatan kasus HIV/AIDS. Pada tahun 2014 terdapat 15 kasus, tahun 2015 terdapat 21 kasus dan tahun 2016 terdapat 24 kasus.

Hasil wawancara dengan Koperasi Tenaga Kerja Bongkat Muat (KOPERBAM) Teluk Bayur, diketahui bahwa beberapa orang TKBM memiliki perilaku berisiko tertular HIV/AIDS, dimana adanya kegiatan pembelian seks oleh TKBM. Hal ini dikarenakan lokasi pelabuhan dekat dengan lokasi prostitusi yang ada di Kota Padang. Walalupun lokasi prostitusi bukan berupa lokalisasi, akan tetapi pada lokasi ini selalu terdapat aktivitas prostitusi. Jarak yang dekat antara pelabuhan dengan lokasi prostitusi, menyebabkan TKBM memiliki akses yang mudah untuk melakukan kegiatan berisiko tertular HIV/AIDS.

Penelitian ini bertujuan untuk mengetahui hubungan karakteristik dan tekanan sosial dengan perilaku berisiko penularan HIV/AIDS pada Tenaga Kerja dengan pendekatan Helath Belief Model pada Tenaga Kerja Bongkar Muat di Kota Padang.

\section{METODE PENELITIAN}

Penelitian ini bersifat analitik dengan desain cross. Penelitian ini dilaksanakan di Pelabuhan Kota Padang dari bulan FebruariMei 2019. Populasi pada penelitian ini adalah seluruh TKBM yang ada di pelabuhan Kota Padang yang berjumlah 834 orang. Teknik pemilihan sampel yang digunakan yaitu cluster sampling. Jumlah sampel untuk masing-masing lokasi, dihitung berdasarkan proporsinya yaitu 82 orang di Pelabuhan Teluk Bayur dan 8 orang di Pelabuhan Muara Padang. Analisis data berupa analisis univariat untuk untuk memperoleh gambaran pada masing-masing variabel independen dan dependen analisis bivariat untuk menguji ada tidaknya hubungan setiap variabel independen dengan dependen dengan uji chi square pada tingkat kepercayaaan $95 \%$ ( $\mathrm{p}<$ $0,05)$.

\section{HASIL DAN PEMBAHASAN}

\section{Hubungan Persepsi Kerentanan dengan Perilaku Berisiko Penularan HIV/AIDS}

Hasil penelitian tentang hubungan persepsi kerentanan dengan perilaku pencegahan HIV/AIDS pada TKBM. Berdasarkan tabel 1 dapat diketahui bahwa responden dengan persepsi kerentanan baik lebih banyak memiliki perilaku tidak berisiko dalam penularan HIV/AIDS (72,1\%) dibandingkan responden dengan persepsi kerentanan yang tidak baik $(53,2 \%)$. Hasil uji statistik diperoleh nilai $\mathrm{P}$ Value 0,065 yang berarti tidak terdapat hubungan yang bermakna antara persepsi kerentanan dengan perilaku pencegahan penularan HIV/AIDS.

Penelitian ini bersebrangan dengan penelitian Wulandari, dkk menunjukan bahwa ada pengaruh antara persepsi kerentanan dengan perilaku pencegahan IMS pada WPS di Banjarsari Surakarta secara signifikan $\mathrm{p}=0.012$, dimana 
Tabel 1

Hubungan Persepsi Kerentanan dengan Perilaku Berisiko Penularan HIV/AIDS pada TKBM di Pelabuhan Kota Padang Tahun 2019

\begin{tabular}{|c|c|c|c|c|c|c|c|c|}
\hline \multirow{3}{*}{ No } & \multirow{3}{*}{ Pengetahuan } & \multicolumn{4}{|c|}{$\begin{array}{c}\text { Perilaku Berisiko } \\
\text { Penularan HIV/AIDS }\end{array}$} & \multicolumn{2}{|c|}{ Jumlah } & \multirow[t]{2}{*}{ P Value } \\
\hline & & \multicolumn{2}{|c|}{$\begin{array}{c}\text { Tidak } \\
\text { Berisiko }\end{array}$} & \multicolumn{2}{|c|}{ Berisiko } & & & \\
\hline & & $\mathbf{F}$ & $\%$ & $\mathbf{F}$ & $\%$ & $\mathbf{F}$ & $\%$ & \\
\hline 1 & Baik & 32 & 61,5 & 20 & 38,5 & 52 & 100 & \\
\hline 2 & Tidak Baik & 24 & 63,2 & 14 & 36,8 & 38 & 100 & 0,876 \\
\hline & Jum & 56 & 62,2 & 34 & 37,8 & 90 & 100 & \\
\hline
\end{tabular}

Tabel 2.

Hubungan Persepsi Keparahan dengan Perilaku Berisiko Penularan HIV/AIDS pada TKBM di Pelabuhan Kota Padang Tahun 2019

\begin{tabular}{|c|c|c|c|c|c|c|c|c|}
\hline \multirow{3}{*}{ No } & \multirow{3}{*}{$\begin{array}{l}\text { Persepsi } \\
\text { Kerentanan }\end{array}$} & \multicolumn{4}{|c|}{$\begin{array}{c}\text { Perilaku Berisiko } \\
\text { Penularan HIV/AIDS }\end{array}$} & \multirow{2}{*}{\multicolumn{2}{|c|}{ Jumlah }} & \multirow{3}{*}{ P Value } \\
\hline & & \multicolumn{2}{|c|}{$\begin{array}{c}\text { Tidak } \\
\text { Berisiko }\end{array}$} & \multicolumn{2}{|c|}{ Berisiko } & & & \\
\hline & & $\mathbf{F}$ & $\%$ & $\mathbf{F}$ & $\%$ & $\mathbf{F}$ & $\%$ & \\
\hline 1 & Baik & 31 & 72,1 & 12 & 27,9 & 43 & 100 & \multirow{3}{*}{0,065} \\
\hline \multirow[t]{2}{*}{2} & Tidak Baik & 25 & 53,2 & 22 & 46,8 & 47 & 100 & \\
\hline & Jumlah & 56 & 62,2 & 34 & $\mathbf{3 7 , 8}$ & 90 & 100 & \\
\hline
\end{tabular}

semakin kuat persepsi kerentanan seorang WPS, maka akan semakin besar kemungkinan memiliki perilaku sehat dalam pencegahan IMS (5). Akan tetapi, penelitian ini sejalan dengan penelitian Umam, et.al yang menunjukkan bahwa persepsi kerentanan tidak berhubungan dengan perilaku pencegahan HIV pada Mahasiswa Universitas di Indonesia tahun 2017 (6). Penelitian ini tidak menunjukkan adanya hubungan yang bermakna antara persepsi kerentanan dengan perilaku berisiko penularan HIV/AIDS. Walaupun TKBM memiliki anggapan terhadap kerentanan untuk tertular HIV/AIDS, akan tetapi perilaku tetap tidak sesuai dengan persepsi mereka, dikarenakan mereka berada di lingkungan yang cukup berisiko.

\section{Hubungan Persepsi Keparahan dengan} Perilaku Berisiko Penularan HIV/AIDS

Hasil penelitian tentang hubungan persepsi keparahan dengan perilaku pencegahan HIV/AIDS pada TKBM di Pelabuhan Kota Padang

Berdasarkan tabel 2 dapat diketahui bahwa responden dengan persepsi keparahan yang baik lebih sedikit memiliki perilaku pencegahan yang tidak berisiko dalam penularan HIV/AIDS $(57,1 \%)$ dibandingkan responden persepsi keparahan tidak baik $(65,5 \%)$. Hasil uji statistik diperoleh nilai $\mathrm{P}$ Value 0,428 yang berarti tidak terdapat hubungan yang bermakna antara persepsi keparahan dengan perilaku berisiko penularan HIV/AIDS.

Penelitian ini tidak sejalan dengan penelitian Barus yang menunjukkan bahwa adanya persepsi keseriusan/keparahan terhadap dampak HIV dengan perilaku berisiko (penggunaan kondom) pada PSK di wilayah kerja Puskesmas Bandar Baru tahun 2015 (7).

Akan tetapi, penelitian ini sejalan dengan penelitian Sirait dan Sarumpaet, 
iTabel 3.

Hubungan Persepsi Manfaat dengan Perilaku Berisiko Penularan HIV/AIDS pada TKBM di Pelabuhan Kota Padang Tahun 2019

\begin{tabular}{|c|c|c|c|c|c|c|c|c|}
\hline \multirow{3}{*}{ No } & \multirow{3}{*}{$\begin{array}{l}\text { Persepsi } \\
\text { Manfaat }\end{array}$} & \multicolumn{4}{|c|}{$\begin{array}{c}\text { Perilaku Berisiko } \\
\text { Penularan HIV/AIDS }\end{array}$} & \multirow{2}{*}{\multicolumn{2}{|c|}{ Jumlah }} & \multirow{2}{*}{ P Value } \\
\hline & & \multicolumn{2}{|c|}{$\begin{array}{c}\text { Tidak } \\
\text { Berisiko }\end{array}$} & \multicolumn{2}{|c|}{ Berisiko } & & & \\
\hline & & $\mathbf{F}$ & $\%$ & $\mathbf{F}$ & $\%$ & $\mathbf{F}$ & $\%$ & \multirow{4}{*}{0,254} \\
\hline 1 & Baik & 30 & 68,2 & 14 & 31,8 & 44 & 100 & \\
\hline 2 & Tidak Baik & 26 & 56,5 & 20 & 43,5 & 46 & 100 & \\
\hline & Jumlah & 56 & 62,2 & 34 & 37,8 & 90 & 100 & \\
\hline
\end{tabular}

yang menunjukkan bahwa persepsi keseriusan/keparahan tidak memiliki hubungan dengan penggunaan kondom pada anak buah kapal di Pelabuhan Blawan (8).

Tidak adanya hubungan antara persepsi keparahan dengan perilaku pencegahan penularan HIV/AIDS pada penelitian ini kemungkinan disebabkan oleh karena faktor lain. Walaupun beberapa TKBM menganggap memiliki persepsi serius terhadap keparahan penularan penyakit HIV/AIDS, akan tetapi TKBM masih banyak yang memiliki perilaku yang tidak baik dalam pencegahan penularan HIV/AIDS. Perilaku ini didorong oleh lokasi tempat kerja TKBM yang berada dekat dengan lokasi risiko penularan HIV/AIDS.

Seseorang harus merasakan HIV /AIDS sebagai infeksi serius, sehingga memiliki konsekuensi dan implikasi yang parah pada fisik mereka dan kehidupan sosial, sebelum mereka mengadopsi tindakan pencegahan (seperti penggunaan kondom yang konsisten) terhadap infeksi HIV / AIDS (9).

\section{Hubungan Persepsi Manfaat dengan Perilaku Berisiko Penularan HIV/AIDS}

Hasil penelitian tentang hubungan persepsi manfaat dengan perilaku pencegahan HIV/AIDS pada TKBM di Pelabuhan Kota Padanga. Berdasarkan tabel 3 dapat diketahui bahwa responden dengan persepsi manfaat yang baik lebih banyak memiliki perilaku pencegahan yang tidak berisiko dalam penularan HIV/AIDS $\quad(68,2 \%)$ dibandingkan responden persepsi manfaat tidak baik $(56,5 \%)$. Hasil uji statistik diperoleh nilai $\mathrm{P}$ Value 0,254 yang berarti tidak terdapat hubungan yang bermakna antara persepsi manfaat dengan perilaku berisiko penularan HIV/AIDS.

Penelitian ini sejalan dengan penelitian Mindayani dan Hidayat yang menunjukkan bahwa persepsi manfaat tidak memiliki hubungan dengan perilaku pencegahan penularan HIV/AIDS pada WBP di Lapas Kelas IIA Padang Tahun 2018 (10).

Menurut Bartholomew LK, et al dalam Tarkang, Teori Health Belief Model menjelaskan bahwa kepercayaan orang tentang apakah mereka berisiko atau tidak dengan penyakit HIV/AIDS dan persepsi mereka terhadap manfaat untuk menghindari risiko penularan dengan penggunaan kondom yang konsisten, dapat mempengaruhi kesiapan mereka untuk mengambil tindakan dalam penggunaan kondom secara konsisten saat berhubungan seks untuk mencegah HIV / AIDS (11)(11).

Berbeda dengan hasil penelitian di Pelabuhan Kota Padang. Persepsi manfaat pada TKBM tidak menunjukkan adanya 
Tabel 4.

Hubungan Persepsi Hambatan dengan Perilaku Berisiko Penularan HIV/AIDS pada TBBM di Pelabuhan Padang Tahun 2019

\begin{tabular}{|c|c|c|c|c|c|c|c|c|}
\hline \multirow{3}{*}{ No } & \multirow{3}{*}{$\begin{array}{l}\text { Persepsi } \\
\text { Hambatan }\end{array}$} & \multicolumn{4}{|c|}{$\begin{array}{l}\text { Perilaku Pencegahan } \\
\text { Penularan HIV/AIDS }\end{array}$} & \multirow{2}{*}{\multicolumn{2}{|c|}{ Jumlah }} & \multirow{3}{*}{ P Value } \\
\hline & & \multicolumn{2}{|c|}{$\begin{array}{c}\text { Tidak } \\
\text { Berisiko }\end{array}$} & \multicolumn{2}{|c|}{ Berisiko } & & & \\
\hline & & $\mathbf{F}$ & $\%$ & $\mathbf{F}$ & $\%$ & $\mathbf{F}$ & $\%$ & \\
\hline 1 & Baik & 25 & 64,1 & 14 & 35,9 & 39 & 100 & \\
\hline 2 & Tidak Baik & 31 & 60,8 & 20 & 39,2 & 51 & 100 & 0,748 \\
\hline & Jumlah & 56 & 62,2 & 34 & 37,8 & 90 & 100 & \\
\hline
\end{tabular}

hubungan dengan perilaku berisiko penularan HIV/AIDS. Hal ini kemungkinan disebabkan oleh karena lingkungan TKBM bekerja. Walaupun sebagian besar TKBM mengetahui manfaat jika menghindari risiko penularan HIV/AIDS, akan tetapi dengan adanya kecenderungan teman yang mengajak perilaku berisiko tertular HIV/AIDS, menyebabkan pemahaman mengenai manfaat menghindari perilaku berisiko diabaikan oleh TKBM. Selain itu, beberapa TKBM juga pernah dipaksa melakukan hubungan seksual $(11,1 \%)$, yang menyebabkan secara tidak langsung, TKBM terpaksa melakukan perilaku berisiko untuk tertular HIV/AIDS.

\section{Hubungan Persepsi Hambatan dengan} Perilaku Berisiko Penularan HIV/AIDS

Hasil penelitian tentang hubungan persepsi hambatan dengan perilaku pencegahan HIV/AIDS pada TKBM di Pelabuhan Kota Padang.

Berdasarkan tabel 4 dapat diketahui bahwa responden dengan persepsi hambatan yang baik lebih sedikit memiliki perilaku tidak berisiko dalam penularan HIV/AIDS (25 orang) dibandingkan responden persepsi hambatan tidak baik (31 orang). Hasil uji statistik diperoleh nilai $\mathrm{P}$ Value 0,748 yang berarti tidak terdapat hubungan yang bermakna antara persepsi hambatan dengan perilaku berisiko penularan HIV/AIDS pada TKBM di Pelabuhan Kota Padang.

Persepsi hambatan merupakan hambatan yang dirasakan mengacu pada keyakinan seseorang pada kenyataan dan biaya psikologis atas perilaku yang disarankan. Penelitian ini tidak sejalan dengan penelitian Wulandari, dkk yang menunjukkan adanya pengaruh antara persepsi hambatan dengan perilaku pencegahan IMS pada WPS di Banjarsari Surakarta (5)(5). Penelitian ini juga tidak sesuai dengan Ghaffari yang menyatakan bahwa adanya hubungan yang signifikan dan tidak langsung antara hambatan yang dirasakan dengan perilaku pencegahan penularan HIV/AIDS (tidak melakukan hubungan seksual sebelum menikah) pada pemuda di Shiraz, Iran. Dengan meningkatnya hambatan yang dirasakan, niat seseorang untuk tidak melakukan hubungan seksual pranikah akan berkurang (12).

\section{Hubungan Persepsi Dorongan dengan} Perilaku Berisiko Penularan HIV/AIDS Hasil penelitian tentang hubungan dorongan dengan perilaku berisiko HIV/AIDS pada TKBM di Pelabuhan Kota Padang. 
Tabel 5

Hubungan Dorongan dengan Perilaku Berisiko Penularan HIV/AIDS pada TKBM di Pelabuhan Kota Padang Tahun 2019

\begin{tabular}{|c|c|c|c|c|c|c|c|c|}
\hline \multirow{3}{*}{ No } & \multirow{3}{*}{$\begin{array}{c}\text { Persepsi } \\
\text { Hambatan }\end{array}$} & \multicolumn{4}{|c|}{$\begin{array}{l}\text { Perilaku Pencegahan } \\
\text { Penularan HIV/AIDS }\end{array}$} & \multirow{2}{*}{\multicolumn{2}{|c|}{ Jumlah }} & \multirow{3}{*}{ P Value } \\
\hline & & \multicolumn{2}{|c|}{$\begin{array}{c}\text { Tidak } \\
\text { Berisiko }\end{array}$} & \multicolumn{2}{|c|}{ Berisiko } & & & \\
\hline & & $\mathbf{F}$ & $\%$ & $\mathbf{F}$ & $\%$ & $\mathbf{F}$ & $\%$ & \\
\hline 1 & Baik & 25 & 64,1 & 14 & 35,9 & 39 & 100 & \multirow{3}{*}{0,748} \\
\hline 2 & Tidak Baik & 31 & 60,8 & 20 & 39,2 & 51 & 100 & \\
\hline & Jumlah & 56 & 62,2 & 34 & 37,8 & 90 & 100 & \\
\hline
\end{tabular}

Berdasarkan tabel di atas. dapat diketahui bahwa responden dengan persepsi dorongan yang baik lebih banyak memiliki perilaku tidak berisiko dalam penularan HIV/AIDS $(62,1 \%)$ dibandingkan responden persepsi dorongan tidak baik $(61,8 \%)$. Hasil uji statistik diperoleh nilai $\mathrm{P}$ Value 0,921 yang berarti tidak terdapat hubungan yang bermakna antara persepsi dorongan dengan perilaku pencegahan penularan HIV/AIDS.

Penelitian ini tidak sejalan dengan penelitian Wulandari, dkk (5) yang menyatakan bahwa adanya hubungan antara stimulus/dorongan untuk bertindak dengan perilaku pencegahan IMS pada WPS di Banjarsari Surakarta. Penelitian ini juga tidak didukung oleh Enggarwati (13) yang menyatakan adanya hubungan antara stimulus/dorongan untuk bertindak dengan Perilaku Pencegahan Penularan HIV/AIDS pada Waria Pekerja Seks di Kabupaten Kudus Tahun 2015.

\section{SIMPULAN}

Tidak adanya hubungan antara persepsi kerentanan, persepsi manfaat, persepsi hambatan, persepsi dorongan dengan perilaku berisiko penularan HIV/AIDS di Pelabuhan Kota Padang tahun 2019.

\section{UCAPAN TERIMAKASIH}

Terima kasih penulis ucapkan kepada Yayasan Pendidikan Baiturahmah, LPPM Univeritas Baiturrahmah, FKM Universitas Baiturrahmah, Kemenristekdikti yang telah memberikan bantuan pendanaan dalam penelitian ini.

\section{REFERENSI}

UNAIDS. UNAIDS Data 2017. Reference [Internet]. 2017;246. Available from: http://www.unaids.org

Kementerian Kesehatan. Analisis Kecenderungan Perilaku Berisiko Terhadap HIV Di Indonesia 2007. 2009;

Kementerian Kesehatan. Survei Terpadu Biologis dan Perilaku 2015. 2015;

Dinas Kesehatan Kota Padang. Laporan Tahunan Dinas Kesehatan Kota PadangTahun 2017. 2018;

Wulandari YA, Suryani N, Pamungkasari EP. Health Belief Model: Health Preventive Behavior of Sexually Transmitted Infection in Female Sex Workers in Surakarta. J Heal Promot Behav. 2016;01(02):70-8.

Umam MK, Hemchayat M, Wetasin K. Persepsi tentang HIV/AIDS dan Perilaku Pencegahan HIV pada Mahasiswa Universitas di Indonesia. J Kesehat Reproduksi. 2017;8(1):31-40.

Barus DJ. Hubungan Komponen Health 
Belief Model (HBM) Dengan Penggunaan Kondom Pada Pekerja Seks Komersil (PSK) Di Wilayah Kerja Puskesmas Bandar Baru Tahun 2015. J Mutiara Kesehat Masy. 2017;1(2):9-15.

Sirait LM, Sarumpaet S. Hubungan Komponen Health Belief Model ( HBM ) Dengan Peng- gunaan Kondom Pada Anak Buah Kapal ( ABK ) Di Pelabuhan Be- lawan The Relationship Between Health Belief Model Components And The Use Of Condom Among Ship Crews At Belawan Seaport. J Precure. 2013;1(April):43-9.

Tarkang EE, Zotor FB. Application of the Health Belief Model ( HBM ) in HIV Prevention: A Literature Review. 2015;1(1):1-8.

Mindayani S. Analisis Perilaku Pencegahan Penularan Hiv/Aids Dengan Pendekatan
Health Belief Model (Hbm) Pada Wbp Di Lapas Kelas Iia Padang. J Kesehat. 2019;7621(1):33-43.

Tarkang EE, Pencille LB. Psychosocial predictors of consistent condom use among migrant road construction workers in the southwest region of Cameroon using the health belief model. Pan Afr Med J. 2018;29:1-12.

Ghaffari M, Gharlipour Z, Rakhshanderou S. Related factors of the preventing behaviors of HIV/AIDS among young people: Applying the Extended Health Belief Model (EHBM). Int J Pediatr. 2016;4(8):2317-28.

Enggarwati. Faktor-Faktor yang Berhubungan dengan Perilaku Pencegahan Penularan HIV / AIDS pada Waria Pekerja Seks Di Kabupaten Kudus Tahun 2015. 